\title{
Predicting financial distress in publicly-traded companies
}

\section{Felipe Fontaine Rezende}

Ibmec Rio de Janeiro, Departamento de Administração, Rio de Janeiro, RJ, Brazil

\author{
Roberto Marcos da Silva Montezano \\ Ibmec Rio de Janeiro, Departamento de Administração, Rio de Janeiro, RJ, Brazil \\ Fernando Nascimento de Oliveira \\ Ibmec Rio de Janeiro, Departamento de Economia, Rio de Janeiro, RJ, Brazil
}

\section{Valdir de Jesus Lameira}

Ibmec Rio de Janeiro, Departamento de Administração, Rio de Janeiro, RJ, Brazil

Received on 10.05.2016 - Desk acceptance on 11.01.2016 - $3^{\text {id }}$ version approved on 05.15.2017 - Ahead of print on 07.20.2017

\section{ABSTRACT}

Several models for forecasting bankruptcy have been developed over the years, one of the reasons for which is the important part it plays in decision-making. However, forecasting a company's bankruptcy leaves a very short time for stakeholders to change the situation. It is in this context that this paper arises in order to develop a model for predicting financial distress, which is identified as a step prior to bankruptcy. The predictive model uses the logistic regression technique with panel data and a sample of Brazilian publicly-traded companies with shares listed on the São Paulo Stock, Commodities, and Futures Exchange between 2001 and 2014. As well as financial variables, the final model includes market expectations (macroeconomic) and sector variables. These variables are statistically tested and the hypothesis is confirmed that they improve the accuracy of the model. The research identified the existence of financial distress in $96 \%$ of the companies that went bankrupt. In addition, the relationship between the phenomena of bankruptcy and financial distress is verified, using financial and macroeconomic explanatory variables. The results demonstrate that most (83\%) of the explanatory variables in the model for predicting bankruptcy are also present in the model for predicting the phenomenon of financial distress. The expected gross domestic product variables and the quick ratio, asset turnover, and net equity over total liabilities financial variables are statistically significant in predicting both phenomena. With this evidence, the study suggests the use of the concept of financial distress as a stage prior to bankruptcy and provides a model for predicting financial distress with $89 \%$ accuracy when applied to publicly-traded companies in Brazil in the period examined.

Keywords: financial distress, bankruptcy, prediction, logistic regression, panel data. 


\section{INTRODUCTION}

Models seeking to predict company bankruptcy have been studied with enthusiasm in recent decades in the academic fields (Allen \& Saunders, 2004). Horta, Borges, Carvalho, and Alves (2011) and Horta, Alves, and Carvalho (2013) report that bankruptcy forecasting models offer an advanced tool for analysts and credit managers that is free from subjective influences and that makes it possible to obtain a reliable classification regarding a company's future ability to continue honoring its financial commitments.

In their review concerning bankruptcy forecasting models since 1930, Bellovary, Giacomino, and Akers (2007) reach the conclusion that, despite the differences that exist between the forecasting models, the empirical tests for most show a high predictive ability, suggesting that they are useful for many groups, including auditors, managers, creditors, and analysts.

However, Pinheiro, Santos, Colauto, and Pinheiro (2009) stress the importance of updating these models, due to the loss in validity of the coefficients associated with the variables over time. Balcaen and Ooghe (2004) highlight that these losses mainly occur in models that only contemplate financial variables as they do not consider macroeconomic conditions. In not doing so, these models implicitly assume that the relationship between the variables is stable over time.

With regards to the methods used, Platt and Platt (2006) explain that the models that use the classification of bankruptcy ultimately predict a situation that is practically irreversible for the company and do not leave enough time for stakeholders to be able to make changes. Tinoco and Wilson (2013) note that the legal definition of bankruptcy is not without criticism and bankruptcy can be a slow process, in which the "legal" date of bankruptcy formalization may not represent the "economic" date; that is, the real event of company failure.

Balcaen and Ooghe (2004) complement this by raising other criticisms regarding the use of bankruptcy. They comment that the classification of bankruptcy will depend on the current legislation in each country, and consequently, models developed in different countries will present different definitions of bankruptcy. Moreover, the use of one legal definition of bankruptcy can result in contaminated samples that will interfere in the accuracy of the forecasting model. Companies in financial distress that are about to go bankrupt can undergo incorporation or acquisition processes and are not classified as bankrupt.
At the same time, stable and financially healthy companies can enter into the bankruptcy process for strategic reasons, without there being any relationship with financial distress.

This study opts to work with the theoretical concept of financial distress. The main objective is to develop a predictive model that identifies a stage before company bankruptcy; that is, financial distress. This model has the differential of being able to identify a situation in which the interested parties would have enough time to act before the company goes into a state of bankruptcy.

Moreover, the aim of this study is to develop a forecasting model that includes not only microeconomic (financial) variables, but also macroeconomic and sector variables that portray the environment experienced by companies, thus providing a wider understanding of the phenomenon studied. Sun, Huang, and He (2014) claim that it is necessary to break this traditional view of quantitative models based exclusively on financial indicators and use non-financial information in order to widen the studies on forecasting bankruptcy.

Before developing the model, the study verifies whether the event of financial distress really precedes the bankruptcy stage. For this, two hypotheses are raised and tested:

$\mathbf{H}_{1}$ : bankrupt companies should be classified as being in financial distress at some point in their lifecycle;

$\mathbf{H}_{2}$ : the variables explaining the phenomenon of financial distress should be similar, or at least one of them should, to the variables explaining the phenomenon of bankruptcy.

The results obtained identify that $96 \%$ of the bankrupt companies in the sample were classified as being in financial distress. The models for forecasting financial distress and bankruptcy that were generated presented some similar explanatory variables. Thus, both hypotheses are confirmed, indicating the use of the theoretical concept of financial distress as an event prior to bankruptcy.

The article develops a model for forecasting financial distress based on a quarterly sample of publiclytraded companies with shares on the São Paulo Stock, Commodities, and Futures Exchange (BM\&FBOVESPA) between 2001 and 2014, totaling 11,147 cases.

The final model contemplates a combination of financial, market expectations (macroeconomic), and sector variables, all statistically significant for a confidence interval of $95 \%$. The model is accurate for $89 \%$ of the 
cases and performs satisfactorily compared with the main Brazilian prediction studies (Altman, Baidya \& Dias, 1979; Brito \& Assaf Neto, 2008; Elizabetsky, 1976; Kanitz, 1976; Matias 1978; Sanvicente \& Minardi, 1998; Silva, 1982).

Korol and Korodi (2010) report that no single factor is responsible for a company's bankruptcy. There is a consensus on the existence of two groups of factors. The first involves endogenous causes, which occur within a company and are related to inefficient asset allocation, to an inefficient funding structure, and/or inadequate company management. The second group refers to exogenous causes, which consist of phenomena related with a country's general economic situation and with the fiscal, monetary, and exchange rate policies of the government authority. Companies cannot influence these factors. However, such factors affect companies' financial situation.

The final model covers these two groups of factors by means of the financial and macroeconomic variables. The financial variables constitute company information using coefficients and percentage indices extracted from the companies' accounting statements, which makes it possible to interpret the economic-financial situation and make inferences regarding the future tendency for a company (Hein, Pinto \& Beuren, 2012). The macroeconomic variables add the business environment in which the company is operating to the forecast (Korol \& Korodi,
2010; Tinoco \& Wilson, 2013; Tomas \& Dimitri, 2011).

The model also includes a dummy variable for sector, in accordance with the methodology proposed by Chava and Jarrow (2004), with the aim of measuring the sector effect as a component in predicting financial distress.

The paper contributes to the academic literature by presenting evidence for the use of the theoretical concept of financial distress, making it possible to develop forecasting models that identify a stage prior to company bankruptcy.

In relation to the choice of variables, the results found in the tests support the claim that a model that contemplates microeconomic and macroeconomic variables presents greater predictive power than a model that only contemplates financial variables. The study also introduces the use of market expectations variables, which were statistically significant. A model for forecasting financial distress is presented, which is useful for academics, investors, and capital market analysts.

After this introduction, the article is structured in the following way: section 2 defines the concept of financial distress and identifies the main models for forecasting bankruptcy, section 3 details the samples and the bankruptcy forecasting model, section 4 presents the results, and section 5 contemplates the conclusions, limitations, and suggestions for future studies.

\section{THEORETICAL FRAMEWORK}

\subsection{Theoretical Concept of Financial Distress}

Platt and Platt (2006) report that the concept of financial distress is not defined in a precise way if compared to the legislations that define the processes, such as bankruptcy and liquidation. This indefinition still occurs today, as noted by Soares and Rebouças (2015). However, there are a great number of possible events that can characterize, whether in isolation or together, the state of company financial distress. Platt and Platt (2006) affirm that the state of financial distress precedes practically all bankruptcies, except those due to sudden and unexpected events, such as natural disasters, judicial decisions, or changes in regulation by the government.

The studies that seek to classify companies in financial distress show similarities due to the presence of indices that can identify a company having problems honoring its obligations. Wruck (1990) defines that a company is in financial distress when its cash flow is insufficient to cover its current obligations. Asquith, Gertner, and Scharfstein (1991) report that whether a company is in financial distress depends on its interest coverage ratio, which is calculated using earnings before interest and taxes, depreciation, and amortization (EBITDA) and financial expenses. Andrade and Kaplan (1998) also make use of the EBITDA and of values of financial expenses to classify a company in financial distress. As well as using these indices, Whitaker (1999) considers market value to be a selection criterion, since all companies included in the sample presented a decline in their market value or in the market value corrected for their sector in the year they entered into financial distress.

Finally, the study from Pindado, Rodrigues, and de la Torre (2008) makes a compilation of these papers and adopts a definition of financial distress that evaluates the ability of a company to satisfy its financial obligations in accordance with two conditions: (i) its earnings before interest and taxes, depreciation, and amortization 
(EBIDTA) are lower than its financial expenses for two consecutive years, leading the company to a situation where it can not generate sufficient resources in its operating activities to fulfill its financial obligations; (ii) a fall in its market value between two consecutive periods. Thus, the year after the occurrence of both events is defined as one of entering into financial distress.

Tinoco and Wilson (2013) use this methodology in their predictive study for companies listed on the London Stock Exchange. In their explanation for choosing this approach, for the first condition, when the EBITDA is lower than spending on interest on company debt, they conclude that the company's operating profitability is insufficient to cover its financial obligations. In relation to the second condition, they highlight the same affirmation from Pindado et al. (2008), in which the market, as well as the interested parties, are susceptible to negatively judging a company that suffers from an operating deficit (first condition situation) until an improvement in the company's financial situation is perceived again. Thus, a fall in market value for two consecutive years is interpreted as an indication that a company is experiencing financial distress.

\subsection{Main Models for Forecasting Bankruptcy}

The studies on predicting bankruptcy date back to the 1930s with the analysis of indicators for forecasting bankruptcy starting with the study from Fitzpatrick (1932, apud Bellovary et al., 2007).

Some decades later, Beaver (1966) presented the first study that discussed the use of statistical techniques for predicting bankruptcy; in this case, univariate discriminant analysis. Thirty indices were constructed based on financial statements and from profile analysis it was concluded that bankrupt companies' indices deteriorated much more quickly than those of companies that remained healthy. In his conclusion, he suggested that subsequent studies should use various indicators simultaneously in constructing the models, which would ultimately determine the tendency of subsequent papers with regards to forecasting bankruptcy.

In line with the suggestion from Beaver (1966), Altman (1968) published a study in which a set of financial indices combined with a multivariate discriminant analysis approach would assume greater statistical significance than the technique used up until then, involving comparing the sequential relationship. The model developed, known as Z-score, presented a high ability to predict bankruptcy for one year before entry into bankruptcy ( $95 \%$ accuracy).

Based on the model from Altman, company bankruptcy became a much more widely studied and publicized subject in the academic literature (Horta et al., 2011). The number and complexity of models for forecasting bankruptcy increased drastically (Bellovary et al., 2007).

With the advance in technology, new techniques emerged and new models were developed for predicting bankruptcy. Martins (1977) presented a model for forecasting bankruptcy for banks based on logistic regression. Then, Ohlson (1980) used the logit model (logistic regression) with financial indicators for predicting company bankruptcy and determined that the factors related to probable bankruptcy within the space of a year were company size and measures of financial structure, performance, and liquidity.

Minussi, Damacena, and Ness (2002) report that the advantage of logistic regression compared with multivariate discrimant analysis lies in its coverage of possibilities, given that it is not necessary to guarantee the normality of residues nor the existence of homogeneity of the variance. Moreover, the logistic regression models enable the likelihood of a company going into bankruptcy to be estimated (Balcaen \& Ooghe, 2004).

Also in the 1980s, models emerged that applied artificial intelligence methods, in contrast with the methods developed up until then (statistical methods). Among the artificial intelligence methods, decision trees, neural network techniques, support vector machines, evolved (genetic) algorithms, reasoning based on cases, and rough set, all stand out (Sun et al., 2014).

Sun et al. (2014) comment that both the statistical and artificial intelligence methods present pros and cons. While the statistical methods are constrained by the statistical assumptions, the artificial intelligence methods do not present this constraint, but are much more complex. By using this same approach, Olson, Delen, and Meng (2012) report that due to the complex nature of artificial intelligence models, two relevant modeling characteristics are lost: transparency and transportability. Transparency in the sense of the human ability to understand what the model consists of, and transportability in the sense of the ability to apply the model to new observations. These characteristics, in contrast, are present in the statistical methods, which present a way that can be easily understood and transported.

Besides the technique used, another key element in the theory of company bankruptcy are the explanatory variables, which like the techniques addressed in the model are subject to advances over the years. Korol and Korodi (2010) report that there is no isolated factor that is the cause of company bankruptcy. The authors suggest that there is a consensus regarding two groups of factors 
that result in the event of a company's bankruptcy.

The first concerns endogenous causes, which occur within a company and are the main factors extensively studied and used in the specialized literature on forecasting bankruptcy. The classical models, which began with the work of Altman (1968), used these variables based on specific company information; that is, information obtained from economic-financial reports.

The second group refers to exogenous causes, which consist of phenomena related with a country's general economic situation and with the macroeconomic policies of the governmental authorities. Companies cannot influence these factors; however, such factors affect a company's financial situation, such as its liquidity and its ability to pay.

One of the first studies that defended the use of this second group of variables for forecasting bankruptcy was presented by Johnson (1970). He comments that a company's financial indicators do not contain sufficient information regarding the economic conditions faced by the company's management and by the investors and suggests the use of macroeconomic indicators.

Liou (2007) highlights the study from Rose et al. (1982, apud Liou, 2007) as one of the most significant in the use of macroeconomic variables. The study investigated the relationship between North American company bankruptcy rates and economic indicators between 1970 and 1980 and identified nine economic variables that were statistically related with bankruptcy rates. In their model, they obtained an $\mathrm{R}^{2}$ of 0.91 , confirming the relationship between economic variables and the company bankruptcy process.

Based on these pioneering papers, researchers have come to include and identify macroeconomic variables in studies forecasting bankruptcy or even financial distress (Cuthbertson \& Hudson, 1996; Goudie \& Meeks, 1991; Hudson, 1987; Levy \& Bar-niv, 1987; Liu, 2004, 2009; Platt \& Platt, 1994; Wadhwani, 1986; Zhang, Bessler, and Leatham, 2013).

In their review concerning this topic, Korol and Korodi (2010) report that the main macroeconomic factors that affect company bankruptcy prediction are a country's economic situation, fiscal policy, monetary conditions, inflation, and market characteristics and expectations.

Zhang et al. (2013) identify the same macroeconomic factors as some previous studies (Altman, 1983; Liu, 2004, 2009; Platt \& Platt, 1994) and suggest the use of specific variables to represent the economic factors. With regards to a country's economic situation, they suggest using a general economic index, such as gross domestic product (GDP) or aggregated company earnings. With regards to fiscal policy and monetary conditions, they indicate using the interest rate. In relation to the market, Zhang et al. (2013) report that the share price index or another index are usually used, such as the S\&P 500, which conveys investor expectations for the market as a whole. Inflation is also considered, as it is seen as an important indicator for the economy since it makes companies' earnings more volatile and hampers their ability to pay debts.

Korol and Korodi (2010) and Tomas and Dimitric (2011) conclude that the classical approach to addressing only endogenous factors is obsolete and that there is a logical step in the future of forecasting bankruptcy: the development of predictive models that involves both micro variables and variables linked to the macroeconomic environment in which companies operate.

Altman and Sabato (2007) recognize the qualitative criteria (non-financial variables) as being relevant in the analysis models for forecasting bankruptcy. However, carrying out a literature review regarding the non-financial variables, they perceive their use in the great majority of predictive studies involving small and medium companies. This occurs because such companies, when obliged, present limited financial information (Blanco-Oliver, Irimia-Dieguez, Oliver-Alfonso \& Wilson 2015).

One of the non-financial indicators highlighted by the literature refers to the sector effect (Karkinen \& Laitinen, 2015). Hill, Perry, and Andes (2011) and Mansi, Maxwell, and Zhang (2012) agree that, despite the evidence regarding sector effects, the literature has not paid much attention to this variable in the models. The exception would be the study from Chava and Jarrow (2004), which presents the technique of carrying out a clustering by company into four sectors, using dummy variables, and identifies, statistically, that predictive variables have different weights for different clusters in forecasting bankruptcy. 


\section{METHODOLOGY}

\subsection{Sample}

In order to examine the hypotheses and develop the model for forecasting financial distress, this study uses a sample of non-financial and non-state publicly-traded companies with shares listed on the BM\&FBOVESPA. The analysis period runs from the fourth quarter of 2011 (4Q2001) to the fourth quarter of 2014 (4Q2014). 4Q2001 was chosen because it is the first period in the database for the Brazilian Central Bank's market expectations published by the Executive Management of Investor
Relations of the Brazilian Central Bank (GerênciaExecutiva de Relacionamento com Investidores do Banco Central do Brasil - GERIN).

By using quarterly periods, as presented in Table 1, this study follows the suggestion of Baldwin and Glezen (1992). These authors comment that annual forecasts may not be adequate in rapidly changing economies or when a particular company or industry is experiencing rapid deterioration. Thus, quarterly data have more suitable potential for forecasting.

Table 1 Total observations

\begin{tabular}{|c|c|c|c|c|c|c|c|}
\hline Period & Companies & Period & Companies & Period & Companies & Period & Companies \\
\hline 4Q2001 & 151 & 2Q2005 & 185 & 4Q2008 & 226 & 2Q2012 & 244 \\
\hline 1Q2002 & 162 & 3Q2005 & 188 & 1Q2009 & 227 & 3Q2012 & 244 \\
\hline 2Q2002 & 164 & 4Q2005 & 187 & 2Q2009 & 228 & 4Q2012 & 241 \\
\hline 3Q2002 & 166 & 1Q2006 & 182 & 3Q2009 & 225 & 1Q2013 & 240 \\
\hline 4Q2002 & 168 & 2Q2006 & 180 & 4Q2009 & 222 & 2Q2013 & 236 \\
\hline 1Q2003 & 173 & 3Q2006 & 180 & 1Q2010 & 239 & 3Q2013 & 237 \\
\hline 2Q2003 & 171 & 4Q2006 & 188 & 2Q2010 & 235 & 4Q2013 & 232 \\
\hline $3 Q 2003$ & 171 & 1Q2007 & 199 & 3Q2010 & 233 & 1Q2014 & 231 \\
\hline 4Q2003 & 173 & 2Q2007 & 212 & 4Q2010 & 234 & 2Q2014 & 231 \\
\hline 1Q2004 & 181 & 3Q2007 & 226 & 1Q2011 & 251 & 3Q2014 & 225 \\
\hline 2Q2004 & 178 & 4Q2007 & 224 & 2Q2011 & 255 & 4Q2014 & 218 \\
\hline $3 Q 2004$ & 178 & 1Q2008 & 230 & 3Q2011 & 254 & & \\
\hline 4Q2004 & 184 & 2Q2008 & 233 & 4Q2011 & 242 & & \\
\hline 1Q2005 & 184 & 3Q2008 & 233 & 1Q2012 & 246 & TOTAL & 11,147 \\
\hline
\end{tabular}

Note: as an example, 4Q2001 refers to the fourth quarter of 2001.

Source: Elaborated by the authors.

The information needed to construct the company financial indicators were extracted from the Economática ${ }^{\circ}$ database. Regarding the sample classification for situations of bankruptcy and financial distress, two treatments were used. Companies were classified as being in financial distress when (i) their earnings before interest and taxes, depreciation, and amortization (EBITDA) were lower than their financial expenses for two consecutive periods; (ii) there was a fall in their market value between two consecutive periods. Thus, the period after the occurrence of both events was defined as one of entry into financial distress (Pindado et al., 2008; Tinoco \& Wilson, 2013).

To verify both conditions, the real values for the indicators (EBITDA and financial expenses) and the companies' market value were used. The data were obtained using the Economática ${ }^{\circledR}$ system, and to adjust the data in relation to inflation, the consumer price index (índice de preços ao consumidor - IPCA) was applied.

To classify bankrupt companies, the reports from the Daily Information Bulletin (Boletim Diário de Informações - BID) and the Orientation Supplement published by the BM\&FBOVESPA were used and companies whose shares were traded as being in composition with creditors or in receivership in the period covering 2001 to 2014 were identified. As well as companies in composition with creditors, and in accordance with Brito and Assaf Neto (2008), those companies that appeared as being bankrupt during this period in the Brazilian Securities and Exchange Commission (Comissão de Valores Mobiliários - CVM) registry of publicly-traded companies were also 
considered as being bankrupt. The year in which the bankruptcy event occurred was defined as that in which the company's shares were traded as being in composition with creditors and in which it appeared in the CVM register as being bankrupt.

\subsection{Forecasting Model}

When constructing the models, as well as classifying the event (bankruptcy and financial distress), the explanatory variables and the model's approach technique need to be defined.

Due to the inexistence of a general theory regarding the choice of explanatory variables for forecasting bankruptcy or financial distress, the criteria used for selection are varied (Tascón \& Castano, 2012). In accordance with the conclusions of Korol and Korodi (2010) and Tomas and Dimitric (2011), financial and macroeconomic variables were chosen.
For the financial variables, the same indicators from Brazilian studies on forecasting bankruptcy were used (Altman et al., 1979; Brito \& Assaf Neto, 2008; Elizabetsky, 1976; Kanitz, 1976; Matias, 1978; Sanvicente \& Minardi, 1998; Silva, 1982). These studies were chosen due to their representativeness in the literature, their good predictive ability, and because they use Brazilian companies, the same scope of this article. Cinca, Molinero, and Larraz (2005) explain that the country where a company operates affects the structure of financial indices. Consequently, we sought to use the indicators already tested for companies operating in Brazil.

Thus, the indicators that formed part of the final models from the respective studies were considered. Table 2 identifies all of the indicators mapped and used, while Table 3 describes the abbreviations used in the formulas for the indicators. Table 4 shows the descriptive statistics for the financial variables considered.

Table 2 Inicial financial variables

\begin{tabular}{|c|c|c|c|c|}
\hline Code & Index & Formula & Source & Expected Sign \\
\hline $\mathrm{F} 1$ & Quick ratio & $(C A-I) / C L$ & Kanitz (1976) & Negative \\
\hline $\mathrm{F} 2$ & Net working capital & $(C A-C L) / T A$ & $\begin{array}{c}\text { Altman et al. (1979); } \\
\text { Sanvicente and Minardi (1998); } \\
\text { Brito and Assaf Neto (2008) }\end{array}$ & Negative \\
\hline F3 & General liquidity & $(C A+L T R) / T L$ & Kanitz (1976) & Negative \\
\hline F4 & Cash to sales ratio & $(C F A-C F L) / N R$ & Brito and Assaf Neto (2008) & Negative \\
\hline F5 & Current liquidity & $C A / C L$ & Kanitz (1976) and Matias (1978) & Positive \\
\hline F6 & Receivables to assets & $A R / T A$ & Elizabetsky (1976) & Negative \\
\hline F7 & Total liabilities to funds generation & $T L /(N I+0.1 \times A F A)$ & Silva (1982) & Positive \\
\hline F8 & Indebtedness & $T L / N E$ & Kanitz (1976) & Positive \\
\hline F9 & Suppliers to total assets & $A P / T A$ & Matias (1978) & Positive \\
\hline F10 & Suppliers to sales & $A P / N R$ & Silva (1982) & Positive \\
\hline F11 & Return on equity & $N I / N E$ & Kanitz (1976) & Negative \\
\hline F12 & Net margin & $N I / N R$ & Elizabetsky $(1976)$ & Negative \\
\hline F13 & Earnings before income tax over assets & $E B T / T A$ & Sanvicente and Minardi (1998) & Negative \\
\hline F14 & Operating income over gross income & $E B I T / G I$ & Matias (1978) & Negative \\
\hline F15 & $\begin{array}{l}\text { Operating income plus financial expenses over } \\
\text { assets minus average fixed assets }\end{array}$ & $\begin{array}{c}(E B I T+F E) / \\
(T A-A F A)\end{array}$ & Silva (1982) & Negative \\
\hline F16 & Interest coverage & EBITDA / FE & Sanvicente and Minardi (1998) & Negative \\
\hline F17 & Operational return on assets & $E B I T / T A$ & Altman et al. (1979) & Negative \\
\hline F18 & Short term debt & $C L / T A$ & Elizabetsky (1976) & Positive \\
\hline F19 & Financial debt & $(C F L+L T F L) / T A$ & Brito and Assaf Neto (2008) & Positive \\
\hline F20 & Retained earnings over assets & $(N E-S C) / T A$ & $\begin{array}{l}\text { Sanvicente and Minardi (1998); } \\
\text { Brito e Assaf Neto (2008) }\end{array}$ & Negative \\
\hline F21 & Net equity over assets & $N E / T A$ & Matias (1978) & Negative \\
\hline F22 & Net equity over total liabilities & $N E / T L$ & $\begin{array}{c}\text { Altman et al. (1979); } \\
\text { Sanvicente and Minardi (1998) }\end{array}$ & Negative \\
\hline F23 & Asset turnover & $N R / T A$ & Altman et al. (1979) & Negative \\
\hline
\end{tabular}

Source: Elaborated by the authors. 
Tabela 3 Abbreviations for the indicators

\begin{tabular}{clll}
\hline Abbrev. & \multicolumn{1}{c}{ Description } & Abbrev. & Description \\
\hline AFA & Average fixed assets & I & Inventories \\
\hline AP & Accounts payable & Gl & Gross income \\
\hline AR & Accounts receivable & LTFL & Long term financial liability \\
\hline CA & Current assets & LTR & Long term receiveables \\
\hline CFA & Current financial assets & $\mathrm{NE}$ & Net equity \\
\hline CL & Current liabilities & $\mathrm{NI}$ & Net income \\
\hline CFL & Current financial liabilities & $\mathrm{NR}$ & Net revenue \\
\hline EBIT & Operating income & $\mathrm{SC}$ & Share capital \\
\hline EBT & Earnings before income tax & TA & Total assets \\
\hline EBITDA & Earnings before interest, taxes, depreciation, and & TL & Total liabilities \\
\hline FE & amortization & & \\
\hline
\end{tabular}

$E B I T=$ earnings before interest and taxes

Source: Elaborated by the authors.

Tabela 4 Descriptive statistics for the financial variables $(n=11,147)$

\begin{tabular}{|c|c|c|c|c|}
\hline Variable & Mean & Standard Deviation & Minimum & Maximum \\
\hline F1 & 1.53 & 2.06 & 0.00 & 46.83 \\
\hline F2 & 0.08 & 0.56 & -16.31 & 0.92 \\
\hline F3 & 1.25 & 1.44 & 0.00 & 23.35 \\
\hline $\mathrm{F} 4$ & -8.09 & 219.39 & $-12,352.18$ & $39,835.83$ \\
\hline F5 & 1.92 & 2.20 & 0.00 & 46.83 \\
\hline F6 & 0.15 & 0.12 & 0.00 & 0.98 \\
\hline F7 & 15.86 & 364.13 & $-11,355.88$ & $16,125.79$ \\
\hline F8 & 2.79 & 25.64 & -412 & $1,203.89$ \\
\hline F9 & 0.07 & 0.09 & 0.00 & 1.62 \\
\hline F10 & 0.90 & 8.20 & 0.00 & 467.51 \\
\hline F11 & 0.00 & 0.91 & -44.60 & 10.89 \\
\hline F12 & 0.10 & 17.97 & -638.42 & 731.00 \\
\hline F13 & 0.01 & 0.10 & -3.25 & 1.91 \\
\hline F14 & -0.03 & 26.73 & -866.19 & $1,153.22$ \\
\hline F15 & 0.04 & 0.20 & -6.36 & 7.98 \\
\hline F16 & 3.46 & 122.76 & $-7,670.62$ & $3,891.72$ \\
\hline F17 & 0.02 & 0.07 & -2.95 & 1.74 \\
\hline F18 & 0.35 & 0.53 & 0.00 & 16.40 \\
\hline F19 & 0.34 & 0.76 & 0.00 & 65.98 \\
\hline F20 & -0.12 & 1.95 & -73.19 & 0.82 \\
\hline F21 & 0.22 & 1.83 & -69.37 & 0.99 \\
\hline F22 & 1.25 & 3.83 & -0.99 & 109.44 \\
\hline F23 & 0.21 & 0.17 & 0.00 & 1.94 \\
\hline
\end{tabular}

Source: Elaborated by the authors.

There were also other indicators in the original papers. However, they were not considered, given that a large portion of the sample (companies) did not present the information needed for the calculation.

In relation to the macroeconomic variables, two categories were used. The first refers to the economic indicators observed in each period. For this category, the indicators suggested by Zhang et al. (2013) were considered. To represent a country's macroeconomic situation, the GDP growth rate, the real basic interest rate (SELIC), and the real Bovespa index (Ibovespa) were chosen, as well as inflation measured by the IPCA.
In the second category, the market expectations indicators from the GERIN database were considered. The market expectations survey, as published on the institution's website, aims to monitor the evolution of market expectations for the main macroeconomic variables, providing support for the monetary policy decision-making process. Thus, if these variables provide support that can influence in the monetary policy decision-making process, they ultimately influence the macroeconomic environment and can be useful in predicting this environment. 
Therefore, the study adopted three expectations indicators related to the (contemporary) macroeconomic indicators observed, as shown in Table 5. The period for obtaining the expectations used involved the forecast for 12 months ahead. Table 6 shows the descriptive statistics for the macroeconomic variables considered.

Table 5 Initial macroeconomic variables

\begin{tabular}{ccccc}
\hline Code & Category & Index & Source & Expected Sign \\
\hline M24 & Contemporary & GDP growth rate (\%) & Economática $^{\circledR}$ & Negative \\
\hline M25 & Contemporary & Nominal interest rate (\%) & Economática $^{\circledR}$ & Positive \\
\hline M26 & Contemporary & Inflation (\%) & Economática $^{\circledR}$ & Positive \\
\hline M27 & Contemporary & Real Bovespa Index (points) & Economática $^{\circledR}$ & Negative \\
\hline E28 & Expectation & GDP growth rate (\%) & GERIN & Negative \\
\hline E29 & Expectation & Nominal interst rate $(\%)$ & GERIN & Positive \\
\hline E30 & Expectation & Inflation $(\%)$ & GERIN & Positive \\
\hline
\end{tabular}

GERIN = Executive Management of Investor Relations of the Brazilian Central Bank; GDP= gross domestic product.

Source: Elaborated by the authors.

Table 6 Descriptive statistics for the macroeconomic variables $(n=11,147)$

\begin{tabular}{ccccc}
\hline Variable & Mean & Standard Deviation & Minimum & Maximum \\
\hline M24 & 0.829 & 2.803 & -5.356 & 5.195 \\
\hline M25 & 13.048 & 4.508 & 7.160 & 26.320 \\
\hline M26 & 1.544 & 0.932 & 0.100 & 6.516 \\
\hline E27 & $66,215.16$ & $22,310.34$ & $19,685.20$ & $102,210.96$ \\
\hline E29 & 3.448 & 0.919 & 0.690 & 4.701 \\
\hline E30 & 12.288 & 2.796 & 7.480 & 20.060 \\
\hline
\end{tabular}

Source: Elaborated by the authors.

To construct the dummy variable that identifies the sector effect, this study separated the sample between companies from industry (1) and services (0), using the existing classification in Economática ${ }^{\circ}$ The dummy variable is represented by code I 31 .

With the variables defined, the study then opts to use the logistic regression technique with panel data, based on an unbalanced panel and choosing between the expectation for fixed effects (FE) or random effects (RE), according with the Hausman test results.

The choice of the logistic regression technique is orientated by the positioning of Minussi et al. (2002), Olson et al. (2012), and Sun et al. (2014), as shown in the literature review. The use of panel data enables the simultaneous use of cross-sectional data and time series data (Greene, 2003). The panel not being balanced is the result of the sample used. Since there are companies that entered, or rather, began to trade their shares on the BM\&FBOVESPA and that ceased to trade their shares during the analysis period, the panel is classified as unbalanced. This classification is shown in the statistical software that generates the results (Stata v. 12.0).

\section{RESULTS}

Before developing of the model for predicting financial distress, the hypotheses raised need to be verified to identify if the event of financial distress precedes the event of bankruptcy.
In relation to the first hypothesis, in which bankrupt companies should be classified as being in financial distress at some point in their lifecycle, Tables 7 and 8 were constructed. 
Table 7 Sample behavior in relation to financial distress

\begin{tabular}{lccccc}
\hline & \multicolumn{5}{c}{ Number of times classified as being in financial distress } \\
\hline Solvent $(\%)$ & 0 & 1 & $2-3$ & $4-10$ & $11-20$ \\
\hline Bankrupt $(\%)$ & 100 & 92 & 84 & 78 & 57 \\
\hline Total companies $(\mathrm{n})$ & 0 & 8 & 16 & 22 & 43 \\
\hline
\end{tabular}

Source: Elaborated by the authors.

Table 8 Sample behavior in relation to bankruptcy

\begin{tabular}{cccc}
\hline Bankrupt companies $(\mathbf{n})$ & $\%$ & Classified as being in financial distress \\
\hline 1 & 4 & 0 \\
\hline 3 & 12 & 1 \\
\hline 7 & 28 & $2-3$ & $4-10$ \\
\hline 11 & 44 & $11-20$ \\
\hline 3 & 12 & \\
\hline
\end{tabular}

Source: Elaborated by the authors.

Using these tables, the presence of solvent or bankrupt companies can be verified in accordance with the number of times that the situation of financial distress was identified.

From the data presented in Table 8 , it can be perceived that of all the bankrupt companies identified, only one did not present the situation of financial distress. It bears mentioning that it entered into bankruptcy in 2003. So, as the sample begins at the end of 2001 (fourth quarter), there is no comprehensive time period for this company and the situation of financial distress may have occurred before this period.

By excluding this company, all of the other bankrupt companies were also classified as being in a situation of financial distress; that is, the situation of financial distress may be a stage before the stage of bankruptcy.

Moreover, Table 7 shows that the greater the number of quarters in which a company finds itself in financial distress, the greater the possibility of it being a bankrupt company. The bankruptcy percentages grow from $0 \%$ (when the theoretical situation of financial distress is not identified) to $43 \%$ (when the company presents 11 or more quarters in which financial distress was identified). In this range (11 to 20), one of the companies classified as solvent entered into receivership in 1998, before the analysis period. So, by adjusting its classification to bankrupt, the percentage of bankrupt companies in the latter range would reach $57 \%$ ( 4 out of 7 companies).

As the situation of financial distress is concerned, it is understood that this is a reversible situation; that is, the company will not necessarily enter into bankruptcy. Thus, the existence of solvent companies that have presented periods of financial distress over the period analyzed is seen as normal/predictable.
In relation to the second hypothesis, in which at least some of the explanatory variables for the phenomenon of financial distress should be similar to the explanatory variables for the phenomenon of bankruptcy, the predictive models needed to be developed.

In order to develop the model for predicting financial distress, the following procedure was used:

- At first, only the financial variables were used, as listed in Table 2.

- Due to the great number of variables (23), the presence of multicollinearity was verified using the correlation matrix. For coefficients above 0.8 , one of the variables was excluded (Kennedy, 2009). In this study, the variables current liquidity (F5), short term debt (F18), and net equity over assets (F21) were ignored.

- Then, the stepwise backward procedure was used to identify the statistically significant variables for a $95 \%$ level of confidence. As a sample in the format of panel data is concerned, it is necessary to identify which is the best estimation model (FE or RE). Thus, only the variables that presented a $p$-value lower than 0.05 in both models were excluded.

- In order to choose between the FE and RE method, the Hausman test was carried out. The result from the Hausman test (186.34) presented Prob $>$ chi $2=0.0000$; that is, for a $95 \%$ confidence interval $(p=0.05)$, the null hypothesis can be rejected and it can be affirmed that the FE model is preferable (the quality is more robust) to the RE model.

- Having constructed the final model contemplating only financial variables, the macroeconomic variables listed in Table 3 were then added, followed by the dummy variables for sector (I31). This methodology 
was chosen with the aim of verifying whether the inclusion of these variables improves the model's predictive ability. This hypothesis was confirmed.

- The same procedures for the stage were carried out, contemplating the financial variables.

The final model is presented in Table 9.

Table 9 Model for predicting financial distress

\begin{tabular}{ccccc}
\hline Variable & Coefficient & Standard Error & $\mathbf{Z}$ & $\mathbf{P}>|\mathbf{Z}|$ \\
\hline I31 & 0.84 & 0.29 & -5.68 & 0.003 \\
\hline E28 & -0.32 & 0.06 & -8.66 & 0.000 \\
\hline E29 & -0.21 & 0.02 & 7.76 & 0.000 \\
\hline E30 & 0.32 & 0.04 & -9.03 & 0.000 \\
\hline F1 & -1.34 & 0.15 & -3.67 & 0.000 \\
\hline F2 & -0.33 & 0.09 & 4.19 & 0.000 \\
\hline F9 & 2.84 & 0.68 & 3.82 & 0.000 \\
\hline F22 & 0.06 & 0.02 & -4.86 & 0.000 \\
\hline F23 & -2.74 & 0.57 & -2.76 & 0.000 \\
\hline Const. & -1.30 & 0.47 & 0.006 \\
\hline
\end{tabular}

Note: the dummy variable for the industry (I31) is omitted from the fixed effects model as it concerns a variable that is invariant in time, since in the period analyzed no company altered its commercial characteristic (industry vs. service). The random effects model was thus defined.

Source: Elaborated by the authors.

The final model identified nine statistically significant variables composed of five financial variables [quick ratio (F1), net working capital (F2), suppliers divided by total assets (F9), net equity over total liabilities (F22), and asset turnover (F23)], three macroeconomic variables [GDP expectation (E28), interest rate expectation (E29), and inflation expectation (E30)], and the dummy variable (I31). The probability (P) of a company finding itself in a state of financial distress is given by the following equation:

$$
P=\frac{e^{Z}}{1+e^{Z}}
$$

in which $Z=-1.30-0.84$ I31 -0.32 E28 $-0.21 E 29+$ $0.32 E 30-1.34 F 1-0.33 F 2+2.84 F 9+0.06 F 22-2.74 F 23$

For the model for predicting insolvency, the companies in the sample were previously selected. Once the bankrupt companies ( 25 cases) were identified in the sample, the group of solvent companies ( 25 cases) were selected; that is, for each bankrupt company one solvent company was selected, a procedure also known as the pairing method (Brito \& Assaf Neto, 2008; Kanitz, 1976; Matias, 1978; Sanvicente \& Minardi, 1998).

Having defined the sample, the statistical procedures for the model for predicting financial distress were followed, which led to the construction of the model for predicting bankruptcy, shown in Table 10.

Table 10 Model for predicting bankruptcy

\begin{tabular}{ccccc}
\hline Variable & Coefficient & Standard Error & $\mathbf{Z}$ & $\mathbf{P}>|\mathbf{Z}| \mathbf{P}>|\mathbf{Z}|$ \\
\hline E28 & -0.93 & 0.41 & -2.25 & 0.024 \\
\hline F1 & -10.85 & 3.16 & -3.44 & 0.001 \\
\hline F4 & -0.16 & 0.04 & -3.57 & 0.000 \\
\hline F9 & -55.12 & 16.25 & -3.39 & 0.001 \\
\hline F22 & -14.66 & 3.81 & -3.84 & 0.000 \\
\hline F23 & -28.97 & 8.71 & -3.33 & 0.001 \\
\hline
\end{tabular}

Note: maximun vraisemblance $=-25.492083 ; L R$ chi2 $(7)=111.09 ;$ Prob $>$ chi2 $=0.000$.

Source: Elaborated by the authors. 
Having developed the predictive models, it is observed that of the six variables existing in the model for predicting bankruptcy, five are present in the model for predicting financial distress. Variables E28, F1, and E23 presented the same behavior, while variables F22 and F9 presented diverging signs. Observing the model for financial distress, the F9 variable is in agreement with the sign suggested by the literature, while the sign presented by the F 22 variable is different.

By analyzing variable F22 in isolation, it is understood, based on the literature, that an increase in the proportion of net equity in relation to total liabilities would decrease the chances of a company going into bankruptcy. This occurs because the greater this indicator was, the fewer third-party resources the company would be using, and thus, the lower its obligations would be. Therefore, the expectation was that the variable would present a negative sign, as in the model for predicting bankruptcy. However, by considering this indicator in a more comprehensive way, other behaviors can be raised, especially by analyzing the denominator of indicator F22, total liabilities.

If on one hand an increase in these would lead to a rise in the company's obligations, increasing its probability of going into bankruptcy, on the other their growth could be related to other factors, these being beneficial for the health of the company. A growth in liabilities can be due to some investment that will bring large returns for the company. Moreover, an increase in liabilities may be due to a change in debt profile. In this case, the company uses the rolling debt tool, in which it opts to renegotiate and put off payment of its debts. This renegotiation often occurs as a result of the emergence of new obligations replacing the old ones (which are expiring). Thus, the company presents an increase in liabilities, but by decreasing its short term obligations and reducing its probability of entering into financial distress or into bankruptcy.

It is observed that both hypotheses raised for an increase in liabilities (investment and rolling debt) are more likely to occur in healthy companies. So, companies at risk of bankruptcy (classified as such) have already undergone the financial distress stage. Not being healthy companies, they are unlikely to be able to renegotiate their debts or have sufficient resources to carry out investments. In contrast, companies at risk of financial distress are still classified by the market as healthy, and can use these strategies as a resource in order not to get into financial distress; however, as the data presents, without success.

With regards to the dummy variable for industry (I31), it is perceived that it was not statistically significant. This result was in a way expected, since through using the pairing methodology, for each bankrupt company one solvent company was sought from the same sector. Thus, by using this methodology, the sector variable became a controlled variable.

Having concluded the tests that confirmed the existence of indications that suggest the financial distress stage as a predecessor to bankruptcy, the model for predicting financial distress was defined, as presented in Table 9.

In the model for predicting financial distress that is presented, it is perceived that, as well as variable F22, variable E29 presented a sign that contradicts the literature.

This occurs because a rise in expectations for the interest rate would lead to difficulties for a company to obtain credit, raising the probability of bankruptcy occurring. However, the presence of a negative sign leads to another interpretation of this variable, as presented by Aita, Zani and Silva (2010). Their paper, which aims to identify the micro and macroeconomic variables that determine Brazilian bank failure, also obtained the same (negative) sign for the nominal interest rate (SELIC) variable. In their conclusion, this behavior occurs because the SELIC is lower at times prior to bankruptcy, and it is only after the onset of crisis, effectively when the banks have already declared themselves bankrupt, that the regulatory bodies act (ex post) to contain the situation by raising the rate. That is, in the period in which bankruptcy is predicted, one year before the bank's declaration of bankruptcy, rates are low.

This same interpretation can be used for the market expectations variable. Once a crisis is underway, in other words, after the bankruptcies, the market then projects that the regulatory bodies will react and thus engineer an increase in the interest rate. So, as seen in the paper from Aita et al. (2010), in the period in which financial distress is predicted, the expectations are for a low real interest rate.

In this study, it is observed that both the expectation for interest rates (E29) and the interest rate variable (M25) present a negative sign, with the latter not being statistically significant for a $95 \%$ confidence interval $(p$ $=0.12$ ).

For the industry dummy variable, the study calculated the odds ratio. The fact that a company is from the industrial sector would make the risk of financial distress increase more than twice (2.3) in relation to companies from the services sector. 
Table 11 Odds ratio industry dummy variable

\begin{tabular}{ccccc}
\hline Variable & Odds ratio & Standard Error & $\mathbf{Z}$ & $\mathbf{P}>|\mathbf{Z}| \mathbf{P}>|\mathbf{Z}|$ \\
\hline 131 & 2.33 & 0.66 & 2.98 & 0.0003 \\
\hline
\end{tabular}

Source: Elaborated by the authors.

Having verified the variables, the study concludes the results stage with an analysis of the predictive power of the model by developing a classifications table, using the proportional cut-off value for the sample and constructing the ROC (receiver operating characteristic) curve (Fávero, Belfiore, Silva \& Cham 2009).

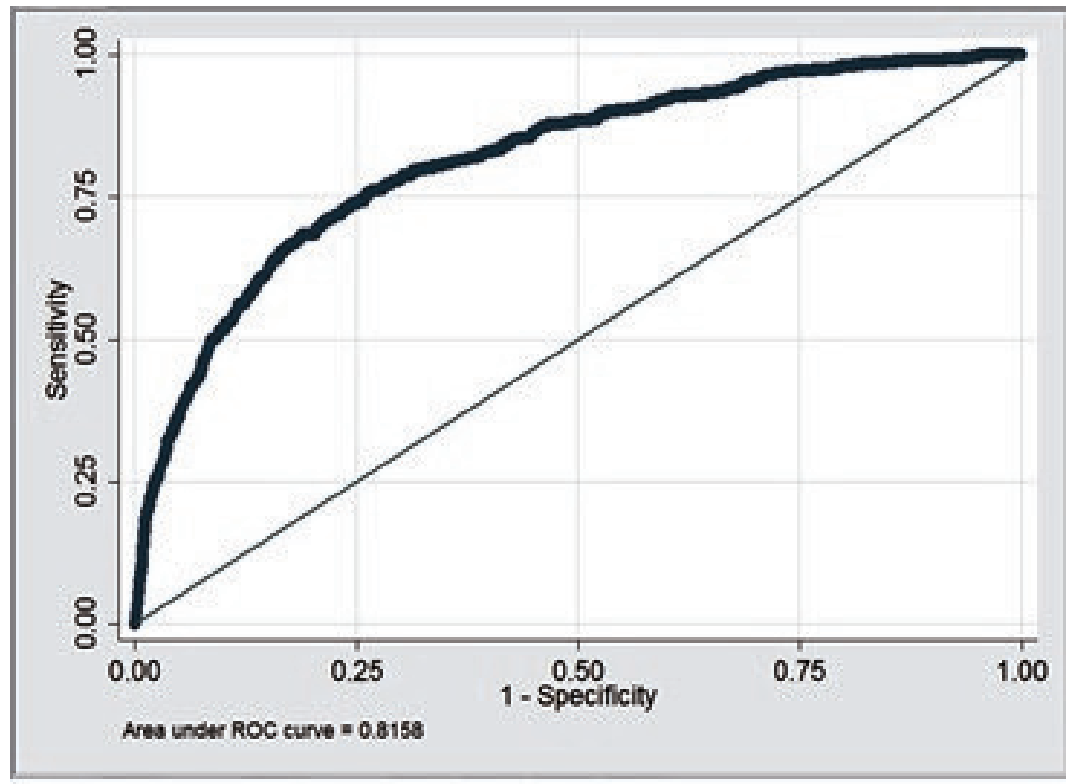

Figure 1 ROC (receiver operating characteristic) Curve.

Source: Elaborated by the authors.

It can be affirmed, referring to the interpretation from Fávero et al. (2009), that the model presents an acceptable discrimination (area greater than 0.7), given that the result from the area under the ROC curve was 0.82 .

Table 12 Classification table

\begin{tabular}{ccc}
\hline & Classification & \\
\hline Sensitivity & Specificity & Model Accuracy \\
\hline $50.0 \%$ & $91.3 \%$ & $89.3 \%$ \\
\hline
\end{tabular}

Source: Elaborated by the authors.

In addition, the summary shown in Table 12 indicates that the model for predicting bankruptcy reached $89 \%$ accuracy. Compared with the main Brazilian studies that were the basis for the financial indicators (Table 13), the model presents a satisfactory performance within the average for the Brazilian models. 
Table 13 Main Brazilian models

\begin{tabular}{lcc}
\hline Model & Sensitivity (\%) & Specificity (\%) \\
\hline Kanitz (1976) & 80 & 68 \\
\hline Elizabetsky (1976) & 74 & 63 \\
\hline Matias (1978) & 70 & 77 \\
\hline Altman et al. (1979) & 83 & 77 \\
\hline Silva (1982) & 90 & 86 \\
\hline Brito and Assaf Neto (2008) & 93 & 90 \\
\hline Sanvicente and Minardi (1998) & 82 & 82 \\
\hline
\end{tabular}

Source: Elaborated by the authors based on Matarazzo (2010).

Despite the predictive power presented by the model $(89 \%)$, it is noted that this result was obtained for the sample that constructed the model itself. Thus, the degree of accuracy is higher than those that should be expected when this model is applied to future samples (Grice \& Ingram, 2001).

In contrast, if the study opted to separate the sample, constructing the model in a test sample (2/3) and calculating its predictive power in a validation sample $(1 / 3)$, it would present limitations in relation to the size of the sample (2/3). The event of financial distress and bankruptcy occurs in a much smaller percentage of the population; thus, a greater amount of data is needed to estimate these models. When including macroeconomic variables it is important for the test sample to contain a reasonable time period, making it possible to cover different economic periods. The constraint that exists in this study, derived from the start of the sampling time (4Q2001) and the number of companies-quarters with shares traded on the BM\&FBOVESPA, limit the sample size, making it difficult to make inferences if the sample is divided/reduced.

Pinheiro et al. (2009) carry out a validation of the main Brazilian models for predicting bankruptcy, using a historic record covering the period from 1995 to 2006, and the variations obtained between the predictive powers calculated in the original models and in the study sample can be verified in Table 14. It is observed that all of the models presented a loss in their predictive power.

Table 14 Updated predictive power of the main Brazilian models

\begin{tabular}{lc}
\hline Model & Variation in overall predictive power (\%) \\
\hline Kanitz (1976) & -16 \\
\hline Elizabetsky (1976) & -23 \\
\hline Altman et al. (1979) & -38 \\
\hline Silva (1982) & -13 \\
\hline Sanvicente and Minardi (1998) & -3 \\
\hline
\end{tabular}

Source: Elaborated by the authors based on Pinheiro et al. (2009).

In relation to this study, this variation is expected to be lower, since the classical models only consider financial variables, while this model assumes the possibility of different macroeconomic conditions (macroeconomic variables) (Balcaen \& Ooghe, 2004).

\section{CONCLUSION}

With the situation of financial crisis in which Brazil finds itself, together with the recent economic crises that the world has experienced, the possibility of increased company bankruptcies is real. Thus, the ability to identify bankruptcy a stage before its occurrence, enabling more time for the planning and implementation of preventative actions and increasing the chances of companies reversing this situation, is a topic that is of considerable relevance.
The concept of financial distress used in the study considers a company to be in financial distress when its EBITDA is lower than its financial expenses for two consecutive periods and when it presents a fall in its market value, also for two consecutive periods.

In accordance with the hypotheses tested, the theoretical concept adopted is shown to be consistent, suggesting that the concept of financial distress can be 
used as a stage prior to bankruptcy. The tests identify that $96 \%$ of the bankrupt companies presented a state of financial distress. Within the six variables that explain the phenomenon of bankruptcy, four are present in the financial distress model.

This study therefore offers a model for predicting financial distress, using variables that not only contemplate the microeconomic situation (financial variables), but also portray the environment experienced by these companies (macroeconomic variables) and the sector to which they belong (industry or services). As a premise, all of the variables have been discussed in previous studies and can be found in sources within the public domain or in the publishings of publicly-traded companies.

The only exceptions were the market expectations variables, which are publicly available, but were not used in previous studies on this topic. However, this exception was shown to be a contribution from the study, given that such variables were statistically significant in predicting financial distress.

The final model identified nine statistically significant variables composed of five financial variables (quick ratio - F1, net working capital - F2, suppliers over total assets - F9, net equity over total liabilities - F22, and asset turnover - F23), three macroeconomic variables (GDP expectation - E28, interest rate expectation - E29, and inflation expectation - E30), and one dummy variable for sector (I31).

In relation to the model's limitations, because it is applied to publicly-traded companies operating in Brazil, it is probable that there would be a loss in the model's accuracy from using the resulting equations in other countries or in privately held companies. The indication, in the case of applying it in other countries, is to follow the methodology of this study, but to generate the model equations by collecting a sample of companies from the country that is the focus of study.

Moreover, the model's predictive power (89\%) was calculated based on the sample used to construct it. The rate of accuracy is expected to be lower when this model is applied to future samples. However, the hope is that this loss will be small, since the model includes variables for macroeconomic effects over time.

For future studies, a broader investigation is suggested that involves market expectations variables, as they were significant in the predictive model.

Moreover, there is the possibility of developing new models for predicting financial distress, by maintaining the theoretical concept applied but employing other statistical techniques and/or artificial intelligence.

\section{REFERENCES}

Aita, J., Zani, J., \& Silva, C. E. S. (2010). Determinantes de insolvência bancária no Brasil: identificação de evidências macro e microeconômicas (Master's dissertation). Universidade do Vale dos Sinos, São Leopoldo.

Allen, L., DeLong, G., \& Saunders, A. (2004). Issues in the credit risk modeling of retail markets. Journal of Banking \& Finance, 28(4), 727-752.

Altman, E. I. (1968). Financial ratios, discriminant analysis and the prediction of corporate bankruptcy. Journal of finance, 23(4), 589-609.

Altman, E. I. (1983). Why businesses fail. Journal of Business Strategy, 3(4), 15-21.

Altman, E. I., \& Sabato, G. (2007). Modelling credit risk for SMEs: evidence from the US market. Abacus, 43(3), 332-357.

Altman, E. I., Baidya, T. K., \& Dias, L. M. R. (1979). Previsão de problemas financeiros em empresas. Revista de Administração de Empresas, 19(1), 17-28.

Andrade, G., \& Kaplan, S. N. (1998). How costly is financial (not economic) distress? Evidence from highly leveraged transactions that became distressed. Journal of Finance, 53(5), 1443-1493.

Asquith, P., Gertner, R., \& Scharfstein, D. (1991). Anatomy of financial distress: an examination of junk-bond issuers. Quarterly Journal of Economics, 109(3), 625-658.

Brito, G. A. S., \& Assaf Neto, A. (2008). Modelo de classificação de risco de crédito de empresas. Revista Contabilidade \& Finanças, 19(46), 18-29.

Balcaen, S., \& Ooghe, H. (2006). 35 years of studies on business failure: an overview of the classic statistical methodologies and their related problems: The British Accounting Review, 38(1), 63-93.

Baldwin, J., \& Glezen, G. W. (1992). Bankruptcy prediction using quarterly financial statement data. Journal of Accounting, Auditing \& Finance, 7(3), 269-285.

Beaver, W. H. (1966). Financial ratios as predictors of failure. Journal of Accounting Research, 4, 71-111.

Bellovary, J. L., Giacomino, D. E., \& Akers, M. D. (2007). A review of bankruptcy prediction studies: 1930 to present. Journal of Financial Education, 33, 1-42.

Blanco-Oliver, A., Irimia-Dieguez, A., Oliver-Alfonso, M., \& Wilson, N. (2015). Improving bankruptcy prediction in micro-entities by using nonlinear effects and non-financial variables. Finance a Uver, 65(2), 144.

Chava, S., \& Jarrow, R. A. (2004). Bankruptcy prediction with industry effects. Review of Finance, 8(4), 537-569.

Cinca, C. S., Molinero, C. M., \& Larraz, J. G. (2005). Country and size effects in financial ratios: a European perspective. Global Finance Journal, 16(1), 26-47.

Cuthbertson, K., \& Hudson, J. (1996). The determinants of compulsory liquidations in the UK. The Manchester School, 64(3), 298-308. 
Elizabetsky, R. (1976). Um modelo matemático para a decisão no banco comercial (Bachelor's Thesis). Departamento de Engenharia de Produção, Escola Politécnica da Universidade de São Paulo, São Paulo.

Fávero, L., Belfiore, P., Silva, F., \& Cham, B. (2009). Análise de dados: modelagem multivariada para tomada de decisão. São Paulo, SP: Campus.

Goudie, A. W., \& Meeks, G. (1991). The exchange rate and company failure in a macro-micro model of the UK company sector. The Economic Journal, 101(406), 444-457.

Greene, W. H. (2003). Econometric analysis. Delhi: Pearson Education India.

Grice, J. S., \& Ingram, R. W. (2001). Tests of the generalizability of Altman's bankruptcy prediction model. Journal of Business Research, 54(1), 53-61.

Hein, N., Pinto, J., \& Beuren, I. M. (2012). Uso da teoria rough sets na análise da solvência de empresas. BASE - Revista de Administração e Contabilidade da Unisinos, 9(1), 68-81.

Hill, N., Perry, S., \& Andes, S. (2011). Evaluating firms in financial distress: an event history analysis. Journal of Applied Business, 12(3), 60-71.

Horta, R. A. M., Borges, C. C. H., Carvalho, F. A. A., \& Alves, F. J. S. (2011). Previsão de insolvência: uma estratégia para balanceamento da base de dados utilizando variáveis contábeis de empresas brasileiras. Sociedade, Contabilidade e Gestão, 6(2), 21-36.

Horta, R. A. M., Alves, F. J. S., \& Carvalho, F. A. A. (2013). Seleção de atributos na previsão de insolvência: aplicação e avaliação usando dados brasileiros recentes. Revista de Administração Mackenzie, 15(1), 125-151.

Hudson, J. (1987). The age, regional, and industrial structure of company liquidations. Journal of Business Finance \& Accounting, 14(2), 199-213.

Johnson, C. G. (1970). Ratio analysis and the prediction of firm failure. Journal of Finance, 25(5), 1166-1168,

Kanitz, S. C. (1976). Indicadores contábeis financeiros previsão de insolvência: a experiência da pequena e média empresa brasileira (Ph.D. Thesis). Faculdade de Economia Administração e Contabilidade, Universidade de São Paulo, São Paulo.

Karkinen, E. L. \& Laitinen, E. K. (2015). Financial and nonfinancial information in reorganisation failure prediction. International Journal Management and Enterprise. Development, 14(2), 144-171.

Kennedy, P. (2009). Manual de econometria (6a. ed.). Rio de Janeiro, RJ: Elsevier.

Korol, T., \& Korodi, A. (2010). Predicting bankruptcy with the use of macroeconomic variables. Economic Computation and Economic Cybernetics Studies and Research, 44(1), 201-221.

Levy, A., \& Bar-niv, R. (1987). Macroeconomic aspects of firm bankruptcy analysis. Journal of Macroeconomics, 9(3), 407415.

Liou, D. K. (2007). Macroeconomic variables and financial distress. Journal of Accounting, Business \& Management, 14, $17-31$.

Liu, J. (2004). Macroeconomic determinants of corporate failures: evidence from the UK. Applied Economics, 36(9), 939-945.
Liu, J. (2009). Business failures and macroeconomic factors in the UK. Bulletin of Economic Research, 61(1), 47-72.

Mansi, S. A., Maxwell, W. F. \& Zhang, A. (2012). Bankruptcy prediction models and the cost of debt. The Journal of Fixed Income, 21(4), 25-42.

Martin, D. (1977). Early warning of bank failure: a logit regression approach. Journal of Banking \& Finance, 1(3), 249-276.

Matarazzo, D. C. (2010). Análise financeira de balanços: abordagem gerencial (7a. ed.). São Paulo, SP: Atlas.

Matias, A. B. (1978). Contribuição às técnicas de análise financeira: um modelo de concessão de crédito (Doctoral Thesis). Departamento de Administração da Faculdade de Economia, Administração e Contabilidade, Universidade de São Paulo, São Paulo.

Minussi, J. A., Damacena, C., \& Ness, W. L., Jr. (2002). Um modelo de previsão de solvência utilizando regressão logística. Revista de Administração Contemporânea, 6(3), 109-128.

Ohlson, J. A. (1980). Financial ratios and the probabilistic prediction of bankruptcy. Journal of Accounting Research, 18, 109-131.

Olson, D. L., Delen, D., \& Meng, Y. (2012). Comparative analysis of data mining methods for bankruptcy prediction. Decision Support Systems, 52(2), 464-473.

Pindado, J., Rodrigues, L., \& de la Torre, C. (2008). Estimating financial distress likelihood. Journal of Business Research, 61(9), 995-1003.

Pinheiro, L. E. T., Santos, C. P., Colauto, R. D., \& Pinheiro, J. L. (2009). Validação de modelos brasileiros de previsão de insolvência. Contabilidade Vista \& Revista, 18(4), 83-103.

Platt, H. D., \& Platt, M. (2006). Comparing financial distress and bankruptcy [Working Paper]. Review of Applied Economics. Retrieved from https://ssrn.com/abstract $=876470$

Platt, H. D., \& Platt, M. B. (1994). Business cycle effects on state corporate failure rates. Journal of Economics and Business, $46(2), 113-127$.

Sanvicente, A. Z., \& Minardi, A. M. A. F. (1998). Identificação de indicadores contábeis significativos para a previsão de concordata de empresas [Working Paper]. Instituto Brasileiro de Mercado de Capitais. Retrieved from http://www.cyta.com. ar/elearn/tc/marterial/altaman5.pdf

Silva, J. P. D. (1982). Modelos para classificação de empresas com vistas à concessão de crédito (Master's dissertation). Escola de Administração de Empresas de São Paulo, Fundação Getúlio Vargas, São Paulo.

Soares, R. A., \& Rebouças, S. M. D. P. (2015). Avaliação do desempenho de técnicas de classificação aplicadas à previsão de insolvência de empresas de capital aberto brasileiras. Revista do Programa de Mestrado em Administração e Desenvolvimento Empresarial da Universidade Estácio de Sá, 18(3), 40-61.

Sun, J., Li, H., Huang, Q. H., \& He, K. Y. (2014). Predicting financial distress and corporate failure: a review from the state-of-the-art definitions, modeling, sampling, and featuring approaches. Knowledge-Based Systems, 57, 41-56.

Tascón, M. T., \& Castaño, F. J. (2012). Variables y modelos para la identificación y predicción del.fracas empresarial: revisión de la investigación empírica reciente. Revista de ContabilidadSpanish Accounting Review, 15(1), 7-58. 
Tinoco, M. H., \& Wilson, N. (2013). Financial distress and bankruptcy prediction among listed companies using accounting, market and macroeconomic variables. International Review of Financial Analysis, 30, 394-419.

Tomas, I., \& Dimitrić, M. (2011, Maio). Micro and macroeconomic variables in predicting financial distress of companies. Anais of International Conference Challenges of Europe: Growth and competitiveness - reversing the trends. Split, Croácia, 9. Retrieved from http://conference.efst.hr/ proceedings/NinthInternationalConferenceChallengesOfEuro pe-ConferenceProceedings-bookmarked.pdf
Wadhwani, S. B. (1986). Inflation, bankruptcy, default premia and the stock market. The Economic Jourial, 96(381), 120-138.

Whitaker, R. B. (1999). The early stages of financial distress. Journal of Economics and Finance, 23(2), 123-132.

Wruck, K. H. (1990). Financial distress, reorganization, and organizational efficiency. Journal of Financial Economics, 27(2), 419-444.

Zhang, J., Bessler, D. A., \& Leatham, D. J. (2013). Aggregate business failures and macroeconomic conditions: a VAR look at the US between 1980 and 2004. Journal of Applied Economics, 16(1), 179-202.

\section{Correspondence address:}

Felipe Fontaine Rezende

Ibmec Rio de Janeiro, Departamento de Administração

Avenida Presidente Wilson, 118 - CEP: 20030-020

Centro - Rio de Janeiro - RJ - Brasil

Email: felipe.fontaine@hotmail.com 